\title{
PENGARUH FINANCIAL LITERACY, MATERIALISM, COMPULSIVE BUYING TERHADAP PROPENSITY TO INDEBTEDNESS
}

\author{
Hendry Kurniawan Wahono ${ }^{1^{*}}$, Dewi Pertiwi ${ }^{2}$ \\ 1,2 Program Finance \& Investment, Program Studi Manajemen \\ Fakultas Bisnis dan Ekonomi, Universitas Kristen Petra \\ Jl. Siwalankerto 121-131, Surabaya \\ E-mail: ${ }^{1} \mathrm{~m} 37415021 @ j o h n . p e t r a . a c . i d ;{ }^{2}$ dewi.pertiwi@petra.ac.id \\ ${ }^{*}$ Penulis korespondensi
}

\begin{abstract}
ABSTRAK
Penelitian ini bertujuan untuk meneliti pengaruh financial literacy, materialism, compulsive buying terhadap perilaku propensity to indebtedness. Populasi dalam penelitian ini adalah masyarakat yang berdomisili dan bertempat tinggal di Surabaya. Sampel yang digunakan berjumlah 185 masyarakat yang berdomisili dan bertempat tinggal di Surabaya. Data dikumpulkan dengan menggunakan kuesioner. Metode analisis data dilakukan dengan menggunakan partial least square. Hasil analisis ini menunjukkan financial literacy, materialism, dan compulsive buying memiliki pengaruh signifikan terhadap propensity to indebtedness.
\end{abstract}

Kata kunci: Financial literacy, materialism, compulsive buying, propensity to indebtedness.

\section{ABSTRACT}

This research aims to examine the impact of financial literacy, materialism, compulsive buying to propensity to indebtedness. The population of this research were people who doimicile and live in Surabaya. Sample which is used for this research is 185 people who doimicile and live in Surabaya. Data were collected by questionnaires and the researcher used partial least square technique in analysing the data. The results of this analysis shows that financial literacy, materialism, and compulsive buying give significant effect on propensity to indebtedness.

Keywords: Financial literacy, materialism, compulsive buying, propensity to indebtedness.

\section{PENDAHULUAN}

Dalam era globalisasi sekarang ini, berbagai pilihan produk dan layanan keuangan yang tersedia bagi masyarakat membuat individu memiliki peluang untuk memaksimalkan fasilitas produk dengan keuntungan yang ditawarkan, namun penting pula untuk memahami resiko dan ketidakpastiannya (OECD, 2012). Resiko yang ada akan membuat individu takut untuk mengambil produk, disertai dengan tidak adanya keterampilan dalam menggunakan produk dan layanan keuangan tersebut (Potrich et al., 2016). Hal ini terkait dengan Propensity to Indebtedness yang merupakan keadaan dimana individu selalu ingin berhutang didalam mendapatkan sesuatu (Davies \& Lea, 1995). Pada umumnya, perilaku Propensity to Indebtedness dapat berpotensi memberikan dampak yang negatif dengan adanya perilaku konsumtif, seperti membeli barang yang sebenarnya untuk kepuasan diri sendiri. Hal ini mengakibatkan individu tidak mempunyai uang yang cukup sehingga mendorong perilaku berhutang, yang pada akhirnya membuat tujuan keuangan, seperti membeli rumah, kendaraan, pendidikan anak, dana pensiun tidak tercapai. Di sisi lain, berhutang memiliki dampak positif bila digunakan untuk tujuan produktif, dimana hutang 
digunakan untuk kegiatan usaha atau berbisnis yang akan mendatangkan hasil dimasa yang akan datang.

Penelitian ini menggunakan 3 (tiga) variabel yang mempengaruhi Propensity to Indebtedness seseorang, yaitu tingkat Financial Literacy, tingkat perilaku Materialism, dan tingkat perilaku Compulsive Buying. Dalam mengelola keuangan untuk menghindari terjadinya perilaku Propensity to Indebtedness, seseorang yang bijak akan mengurangi keinginan untuk berhutang dalam memenuhi kepuasan pribadinya, seseorang juga harus memiliki pengetahuan secara finansial (financial literacy) yang cukup memadai (Huston, 2010). Sedangkan tingkat Materialism yang semakin rendah akan membuat seseorang dapat mengendalikan dirinya untuk tidak berhutang demi hal-hal materi yang dinginkan (Tatzel, 2002). Tingkat perilaku Compulsive Buying yang ditekan akan menghindari terjadinya perilaku Propensity to Indebtness (Tatzel, 2002).

Financial Literacy merupakan hal dasar yang seharusnya dimiliki setiap orang agar terhindar dari permasalahan keuangan. Hal ini didukung dengan penelitian yang menunjukkan bahwa Financial Literacy berpengaruh signifikan terhadap over-indebtedness (Gathergood, 2011). Faktor lain yang mempengaruhi Propensity to Indebtedness seseorang adalah perilaku Materialism. Materialism merupakan perilaku seseorang untuk memiliki barang-barang yang mewah. Seseorang yang memiliki tingkat perilaku Materialism yang rendah akan mampu mengendalikan keuangannya untuk tidak membeli barang-barang yang mewah, sehingga akan terhindar dari perilaku Propensity to Indebtedness. Hal ini didukung oleh penelitian yang dilakukan oleh Tatzel (2002) yang menunjukkan adanya pengaruh signifikan antara tingkat Materialism seseorang terhadap perilaku Propensity to Indebtedness. Faktor terakhir dalam penelitian ini yang mempengaruhi perilaku Propensity to Indebtedness adalah tingkat Compulsive Buying. Compulsive Buying merupakan perilaku dalam membelanjakan barang untuk kepuasan diri sendiri dan belum tentu barang yang dibeli merupakan barang yang dibutuhkan. Dengan tingkat Compulsive Buying yang rendah akan mampu untuk mengendalikan dalam berbelanja barang yang tidak dibutuhkan, sehingga akan mengurangi perilaku Propensity to Indebtedness. Hal ini didukung oleh penelitian yang dilakukan oleh Mowen \& Minor (2002) yang menunjukkan bahwa tingkat Compulsive Buying berpengaruh signifikan terhadap tanggung jawab dalam mengelola hutang.

Penelitian ini bertujuan untuk menganalisis pengaruh Financial Literacy, Materialism, dan Compulsive Buying terhadap Propensity to Indebtedness. Penelitian dilakukan pada masyarakat yang bertempat tinggal di Surabaya dikarenakan Surabaya merupakan ibukota dari propinsi Jawa Timur dan telah menjadi kota Metropolis dengan pusat perdagangan, industri, dan pendidikan di Indonesia (detikfinance, 2014). Hal ini mengindikasikan bahwa dengan menjadi kota Metropolis maka tingkat Financial Literacy masyarakat Surabaya akan tinggi seiring berkembangnya kota Surabaya dan banyak transaksi yang menggunakan jasa bank (Surya, 2017). Tingkat Materialism di Surabaya dapat dilihat dari pajak pertambahan nilai dan pajak pertambahan nilai barang mewah dengan target Rp 6.628 Triliun, realisasinya mencapai Rp 19.855 Triliun dengan presentase sebesar $119,41 \%$ pada tahun 2017 yang mengindikasikan bahwa masyarakat Surabaya banyak yang membeli barang-barang mewah (Surya, 2018). Banyaknya mal di Surabaya mendorong tingkat Compulsive Buying masyarakat Surabaya. Maka peneliti ingin mengetahui pengaruh Financial Literacy, Materialism, dan Compulsive Buying terhadap perilaku Propensity to Indebtedness masyarakat yang bertempat tinggal di Surabaya. 


\section{TEORI PENUNJANG}

\section{Financial Literacy}

Financial Literacy atau Literasi Keuangan dibutuhkan bagi setiap individu karena memberikan manfaat untuk memiliki perencanaan keuangan yang lebih baik, serta terhindar dari masalah keuangan. Setiap individu dapat meningkatkan literasi keuangannya agar dapat membuat keputusan yang baik dan mampu mengoptimalkan keuangan pribadinya. Financial Literacy merupakan pemahaman dalam melakukan pengelolaan keuangan yang berkatian dengan keputusan untuk memanajemen keuangan pribadi, berinvetasi, dan menggunakannya untuk memanajemen resiko yang ada (Chen \& Volpe, 1998). Financial literacy juga merupakan kemampuan untuk membuat keputusan sederhana yang diukur dengan pilihan keuangan seharihari (Lusardi \& Tufano, 2009). Financial literacy didefiniskan sebagai kemampuan individu dalam mengaplikasikan pemahaman keuangan dalam kehidupan sehari-hari (Lusardi \& Mitchell, 2008). Financial literacy dapat diukur ke dalam tiga indikator, yaitu Financial Attitude, Financial Behavior, dan Financial Knowledge karena dari tiga indikator tersebut akan meningkatkan pemahaman tentang keuangan melalui proses membaca, mengelola, menganalisis, serta melakukan komunikasi dari peristiwa yang terjadi dalam kehidupan yang dapat mempengaruhi keputusan keuangan ataupun peristiwa perekonomian yang ada (OECD, 2012; Atkinson \& Messy, 2012).

Menurut Parrotta \& Johnson (1998), dalam penelitiannya menjelaskan bahwa Financial Attitude dikategorikan sebagai personal subsystem. Personal subsystem merupakan gabungan dari faktor sosial dan psikologis, dimana ketika seseorang memiliki rencana keuangan untuk melakukan sebuah investasi keuangan dan memberikan keuntungan, maka akan cenderung mudah untuk melakukan kegiatan sosial dan memiliki psikologis yang baik, karena dapat mengelola keuangannya dengan baik, sehingga tidak menimbulkan stres bahkan depresi secara finansial. Financial Behavior dapat diartikan sebagai kemampuan seseorang dalam menggunakan anggaran untuk rencana pengeluaran dan memiliki tabungan untuk mencapai target keuangan jangka panjang (Shockey, 2002; O'Neill \& Xiao, 2012; OECD, 2013). Financial Knowledge merupakan pengetahuan keuangan dalam memahami informasi yang berkaitan dengan masalah keuangan, seperti mengetahui perbedaan menabung dan berinvestasi, khususnya didalam praktek manajemen keuangan (Van Rooij et al., 2011; OECD, 2013; Klapper et al., 2013; NFCS, 2013).

\section{Materialism}

Menurut Richins (2004), materialisme dideskripsikan sebagai pusat dari hidup (Acquisition Centrality) yang berarti segala yang dimiliki dan diperoleh menjadi pusat hidup seseorang, seperti keinginan memiliki hal-hal yang dapat dikatakan mewah, yaitu rumah, mobil, pakaian mewah secara berlebihan. Materialisme merupakan gaya hidup seseorang dalam mengkonsumsi sesuatu yang berkualitas atau bernilai tinggi; mengejar atau memperoleh kebahagiaan (Acquisition as the Pursuit of Happiness) yang memandang materialisme sebagai sesuatu yang penting dalam mencapai kepuasan dan kesejahteraan hidup; kepemilikan menentukan kesuksesan (Possessiondefined Success) memiliki arti menilai kesuksesan diri sendiri dan orang lain dengan jumlah dan kualitas harta.

\section{Compulsive Buying}

Pembelian kompulsif merupakan suatu gelagat atau tabiat niat beli yang lahir dengan desakan dari dalam diri seseorang akibat adanya rangsangan lingkungan belanja, fenomena ini dapat diartikan 
sebagai suatu aktivitas pembelian secara berulang sebagai akibat dari adanya perasaan yang negatif dikarenakan oleh rasa ketagihan (kecanduan), tertekan, dan rasa bosan (Leite et al., 2011). Bitner et al (1990) menyatakan bahwa implikasi dari lingkungan belanja terhadap perilaku pembelian mendukung asumsi bahwa jasa layanan fisik menyediakan lingkungan yang mempengaruhi perilaku konsumen yang dihubungkan dengan karakteristik lingkungan konsumsi, seperti halnya mengharuskan untuk membelanjakan suatu barang untuk kepuasan mata dan kepuasan diri.

\section{Propensity to Indebtedness}

Hutang diartikan sebagai uang yang dipinjamkan dari orang lain dan ada sebuah kewajiban untuk membayarnya kembali. Sementara Lea et al (1995) mengatakan bahwa hutang merupakan sejumlah uang yang akan diberikan kepada orang lain berhubungan dengan penggunaan barang (jasa). Seseorang dikatakan berhutang pada saat mereka memiliki pinjaman terhadap bank, kartu kredit atau tidak mampu menyelesaikan tagihan. Sementara Fitch (2007) berpendapat bahwa hutang sebagai sebuah tindakan individu dimana uang yang dipinjam di harapkan akan dibayarkan kembali di kemudian hari. Hutang juga berarti kewajiban keuangan yang dimiliki oleh seseorang kepada orang lain sebagai akibat ketidakmampuan memprediksi keadaan dimasa yang akan datang (Erdem, 2008).

\section{Pengaruh Financial Literacy terhadap perilaku Propensity to Indebtedness}

Financial literacy yang baik merupakan sebuah dasar pengetahuan bagi seseorang yang hendak berhutang, serta memiliki keputusan yang tepat dan matang dalam berhutang (Lusardi \& Tufano, 2009). Sedangkan, financial literacy yang buruk dalam pengambilan keputusan akan membuat seseorang menjadi rentan terhadap beragam produk keuangan yang ditawarkan di pasar, sehingga kemungkinan akan mengalami kesulitan keuangan, seperti hutang dan gagal bayar (Lyons, 2004).

\section{Pengaruh Materialism terhadap perilaku Propensity to Indebtedness}

Menurut Ponchio (2006), dengan adanya sikap materialism yang tinggi, semakin tinggi pula propensity to indebtedness, dimana seseorang akan selalu memiliki hasrat yang tinggi untuk memiliki hal-hal materi yang mewah dan segala cara akan dilakukan untuk membelinya walaupun dengan cara berhutang. Gardarsdottir \& Dittmar (2012) menemukan bahwa materialism merupakan faktor penentu seseorang untuk berhutang, bahkan perilaku materialism membuat seseorang lebih bahagia ketika memperoleh pinjaman dari hutang.

\section{Pengaruh perilaku Compulsive Buying terhadap perilaku Peopwnsity to Indebtedness}

Compulsive buying dapat membuat seseorang lebih cenderung untuk mengakumulasi hutang dan akan terjadi penumpukan hutang yang berlebih, karena tuntutan yang timbul melalui perilaku tersebut akan muncul dalam diri seseorang dan memicu tindakan untuk membeli secara berlebihan (Achtziger et al., 2015). Pembelian barang-barang material, seperti tas, pakaian, makeup, kendaraan bermotor, dan lain sebagainya merupakan hal yang wajar, namun dalam situasi tertentu, pembelian yang dilakukan secara mendadak dan tidak terencana, serta terkait dengan dorongan yang tidak terkendali hanya untuk mengikuti perasaan senang dan gembira akan membuat hal tersebut menjadi salah dan akhirnya memaksa untuk membeli walaupun dengan cara berhutang (O'Guinn \& Faber, 1989). 


\section{Pengaruh perilaku Materialism terhadap perilaku Compulsive Buying}

Perspektif dari Dittmar (2004), individu yang berperilaku materialistik akan memiliki harga diri yang rendah dan lebih rentan untuk menunjukkan perilaku compulsive buying sebagai cara untuk meminimalkan perasaan negatif dan mendapatkan pujian yang lebih dari banyak orang. Hubungan antara keduanya memiliki hubungan yang positif, dimana semakin tinggi tingkat materialisme, maka kemungkinan seseorang menjadi pembeli yang kompulsif juga tinggi (Richins, 2004). Materialism memiliki pengaruh terhadap compulsive buying, dimana individu kehilangan kontrol atas dorongan membeli dan melanjutkan pembelian secara berlebihan meskipun menerima konsekuensi yang merugikan (Dittmar, 2004). Pembeli yang kompulsif cenderung akan membeli barang-barang bernilai materialistik sehingga identitas dan harga diri seseorang akan tergantung pada kuantitas dan jenis barang material yang dimiliki (Dittmar, 2004).

\section{Pengaruh Financial Literacy terhadap perilaku Materialism}

Roberts (1998) memberikan rekomendasi untuk menerapkan manajemen keuangan dalam praktek keuangan sebagai tindakan untuk mencegah perilaku materialistik, terdapat tiga cara untuk dapat melakukan manajemen keuangan dengan baik yaitu: konsistensi (consistency), kelangsungan hidup (viability), pengelolaan (stewardship)

\section{Pengaruh Financial Literacy terhdap perilaku Compulsive Buying}

Financial Literacy merupakan suatu hal yang membuat seseorang menjadi melek secara finansial (Chen \& Volpe, 1998). Dengan semakin tinggi tingkat pemahaman yang dimiliki dapat membuat seseorang dapat menahan keinginan untuk membeli barang-barang yang tidak dibutuhkan, karena seseorang menjadi sadar akan pentingnya menabung (Lusardi \& Tufano, 2009). Penelitian Russell et al. (2006) mendukung pencantuman pendidikan keuangan dalam program sekolah dengan harapan mencegah pembelian kompulsif. Pendidikan keuangan dapat diajarkan sedini mungkin agar pada saat sudah memiliki pendapatan, seseorang akan lebih dapat mengatur keuangannya dengan benar dengan tujuan untuk mengetahui mana yang merupakan dorongan keinginan dan mana yang merupakan sebuah kebutuhan. Russell et al. (2006) juga mengatakan bahwa pendidikan keuangan yang diberikan justru akan merubah karakter seseorang menjadi lebih hemat dan dapat menghargai uang yang mereka dapatkan, serta dapat mengalokasikan uang tersebut pada hal-hal yang tepat.

Berdasarkan penjelasan tersebut, maka hipotesa dalam penelitian ini adalah:

1. Financial Literacy berpengaruh signifikan terhadap perilaku Propensity to Indebtedness,

2. Perilaku Compulsive Buying berpengaruh signifikan terhadap perilaku Propensity to Indebtedness.

3. Perilaku Materialism berpengaruh signifikan terhadap perilaku Propensity to Indebtedness.

4. Financial Literacy berpengaruh signifikan terhadap perilaku Compulsive Buying.

5. Financial Literacy berpengaruh signifikan terhadap perilaku Materialism.

6. Materialism berpengaruh signifikan terhadap perilaku Compulsive Buying. 


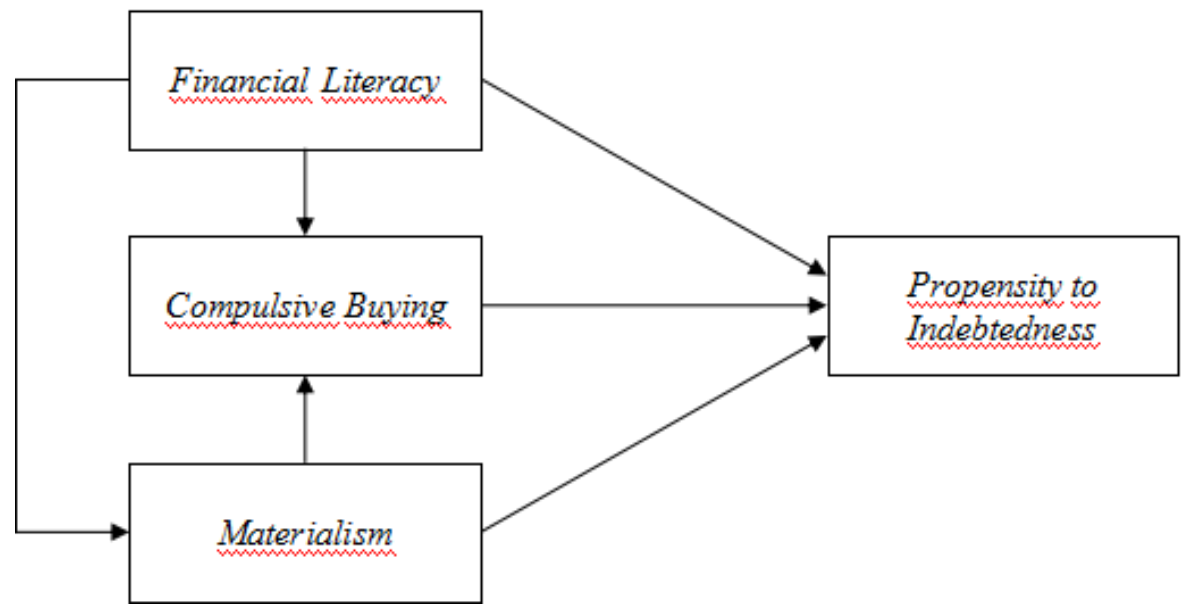

Gambar 1. Kerangka berpikir

\section{METODOLOGI PENELITIAN}

Jenis penelitian yang digunakan adalah penelitian asosiatif dengan jenis data kuantitatif. Populasi dalam penelitian ini adalah masyarakat yang berdomisili dan bertempat tinggal di Surabaya. Karakteristik responden yang menjadi sampel dalam penelitian ini didasarkan pada kriteria memiliki e-KTP (Kartu Tanda Penduduk) min. 17 tahun, karena seseorang dapat dikatakan sudah dewasa dan memiliki keputusan yang matang. Jumlah sampel yang akan diambil dalam penelitian ini minimal sebanyak 60 responden, yang diharapkan dapat mewakili populasi. Alasan mengambil jumlah minimal sampel sebanyak 60 orang merupakan sampel minimal diambil sebanyak 10 kali lipat dari total indikator pada variabel yang paling banyak dipengaruhi. Variabel yang paling banyak dipengaruhi adalah propensity to indebtedness dengan total 6 indikator sehingga sampel minimal sejumlah 60 responden. Pengumpulan data dapat didapatkan dengan cara pembagian kuisioner kepada responden melalui tautan link menggunakan google form dan disebarkan melalui media sosial seperti LINE, Whatsapp, dan Instagram. Analisis statistik menggunakan SEM-PLS dengan alat SmartPLS versi 3.

\section{ANALISA DAN PEMBAHASAN}

Teknik analisa data dilakukan dengan menggunakan pendekatan analisis SEM (Structural Equation Modelling) dengan software Smart PLS (Partial Least Square). Di dalam PLS Path Modelling terdapat 2 model dalam menganalisanya yaitu dengan outer model dan inner model. Pada evaluasi outer model akan dilakukan pengujian convergent validity, discriminant validity dan composite reliability.

\section{Uji Convergent Validity}

Tahap awal yang dilakukan adalah mengkontruksi diagram jalur. Setelah dilakukan analisa, hasil output model pengukuran pertama dan kedua menunjukkan bahwa masih terdapat indikator yang tidak memenuhi nilai outer loading dikarenakan nilainya dibawah ketentuan nilai outer loading > 0,40 , sehingga indikator dengan nilai outer loading terkecil harus dikeluarkan dan dilakukan kembali running data agar dapat memenuhi syarat convergent validity. Setiap indikator dari masing-masing variabel telah memenuhi syarat convergent validity pada hasil output model pengukuran ketiga yang ditunjukkan dalam gambar 3 berikut 


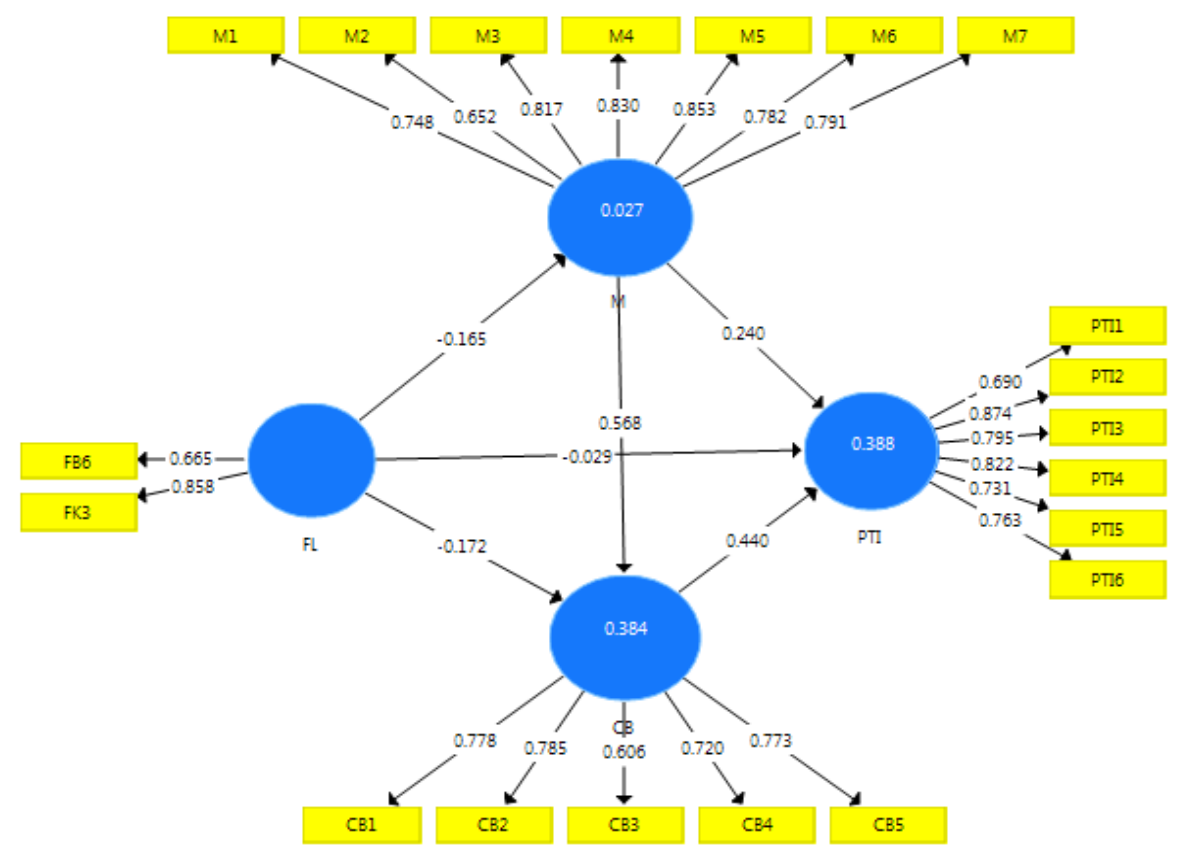

Gambar 3. Konstruksi Diagram Path

Dapat dilihat pada tabel 1 bahwa nilai Average Variance Extracted (AVE) dari masing-masing indikator berada diatas 0,4 sehingga indikator penelitian ini telah memenuhi syarat dalam uji validitas konvergen. Semua indikator pada variabel penelitian memiliki nilai AVE $>0,5$. Berdasarkan hasil tersebut semua indikator pada penelitian ini dinyatakan valid dan dapat digunakan untuk analisis lebih lanjut.

Tabel 1. Outer Loading dan Nilai Average Variance Extracted (AVE)

\begin{tabular}{cccc}
\hline Variabel & Indikator & Outer Loading & $\begin{array}{c}\text { Nilai Average Variance Extracted } \\
\text { (AVE) }\end{array}$ \\
\hline Financial Literacy & FB6 & 0,665 & 0,589 \\
(FL) & FK3 & 0,858 & \\
& M1 & 0,748 & \\
Materialism & M3 & 0,652 & 0,615 \\
(M) & M4 & 0,817 & \\
& M5 & 0,830 & \\
& M6 & 0,853 & \\
& M7 & 0,782 & 0,541 \\
Compulsive Buying & CB1 & 0,791 & \\
(CB) & CB2 & 0,778 & \\
& CB3 & 0,785 & \\
& CB4 & 0,606 & \\
Propensity to & CB5 & 0,720 & \\
Indebtedness & PTI1 & 0,773 & \\
(PTI) & PTI2 & 0,690 & \\
& PTI3 & 0,874 & \\
& PTI4 & 0,795 & \\
& PTI5 & 0,822 & \\
& PTI6 & 0,731 & \\
\hline
\end{tabular}




\section{Discriminant validity}

Uji validitas dilakukan dengan menggunakan Heterotrait-Monotrait. Dari tabel 2 terlihat bahwa skor Heterotrait-Monotrait (HTMT) dibawah 0,9. Maka dapat disimpulkan bahwa data telah memenuhi uji validitas diskriminan.

Tabel 2. Hasil output Heterotrait-Monotrait

\begin{tabular}{lllll}
\hline \multicolumn{5}{c}{ Heterotrait-Monotrait } \\
\hline CB & CB & FL & M & PTI \\
FL & 0,506 & & & \\
M & 0,686 & 0,291 & & \\
PTI & 0,694 & 0,340 & 0,543 & \\
\hline
\end{tabular}

\section{Composite reliability}

Pada tabel 3 terlihat bahwa nilai dari Composite Reliability lebih dari 0,7 maka dapat disimpulkan bahwa semua variabel mempunyai reliabilitas yang baik.

Tabel 3. Composite Reliability

\begin{tabular}{lc}
\hline \multicolumn{1}{c}{ Variabel } & Composite Reliability \\
\hline Financial Literacy (FL) & 0,738 \\
Materialism (M) & 0,917 \\
Compulsive Buying (CB) & 0,854 \\
Propensity to Indebtedness (PTI) & 0,903 \\
\hline
\end{tabular}

\section{Evaluasi Inner Model}

Dari Tabel 4 terlihat bahwa nilai $\mathrm{R}^{2}$ dari Materialism sebagai variabel dependen adalah sebesar 0,027 yang artinya variasi perubahan variabel dependen yang dapat dijelaskan oleh variabel independen financial literacy adalah sebesar 2,7 persen, sedangkan sisanya dijelaskan oleh variabel lainnya di luar model yang diajukan. Nilai $R^{2}$ dari Compulsive Buying sebagai variabel dependen adalah sebesar 0,384 yang artinya variasi perubahan variabel dependen yang dapat dijelaskan oleh variabel independen financial literacy adalah sebesar 38,4 persen, sedangkan sisanya dijelaskan oleh variabel lainnya di luar model yang diajukan.

Tabel 4. R-Square

\begin{tabular}{lc}
\hline \multicolumn{1}{c}{ Variabel } & $\mathbf{R}^{\mathbf{2}}$ \\
\hline Materialism (M) & 0,027 \\
Compulsive Buying (CB) & 0,384 \\
Propensity to Indebtedness (PTI) & 0,388 \\
\hline
\end{tabular}

\section{Uji Hipotesis}

Uji hipotesis dilakukan dengan melihat t-statistic dengan penilaian diterima apabila nilai t-statistic $>1,96$. Berikut untuk menjawab hipotesis penelitian dapat dilihat dari t-statistic tabel 4.23 berikut: 
Tabel 5. Hasil Pengujian Hipotesis dan Nilai t-statistic

\begin{tabular}{clcc}
\hline No. & \multicolumn{1}{c}{ Hipotesis } & t-statistic & Kesimpulan \\
\hline 1. & $\mathrm{FL} \rightarrow \mathrm{PTI}$ & 2,077 & Signifikan \\
2. & $\mathrm{CB} \rightarrow \mathrm{PTI}$ & 6,204 & Signifikan \\
3. & $\mathrm{M} \rightarrow \mathrm{PTI}$ & 7,518 & Signifikan \\
4. & $\mathrm{FL} \rightarrow \mathrm{CB}$ & 3,181 & Signifikan \\
5. & $\mathrm{FL} \rightarrow \mathrm{M}$ & 2,187 & Signifikan \\
6. & $\mathrm{M} \rightarrow \mathrm{CB}$ & 11,617 & Signifikan \\
\hline
\end{tabular}

\section{ANALISA PEMBAHASAN}

\section{Pengaruh Financial Literacy terhadap Propensity to Indebtedness}

Hasil analisis pengaruh financial literacy terhadap propensity to indebtedness mempunyai nilai $t$ statistik sebesar 2,077 yang artinya lebih besar dari 1,96, sehingga menunjukkan bahwa terdapat pengaruh signifikan financial literacy terhadap propensity to indebtedness pada masyarakat yang berdomisili dan bertempat tinggal di Surabaya. Berdasarkan hasil maka hipotesis $\mathrm{H}_{1}$ yaitu "Financial literacy berpengaruh signifikan terhadap perilaku propensity to indebtedness", dinyatakan diterima. Hal ini sejalan dengan pendapat Lusardi \& Tufano (2009) yang menjelaskan bahwa financial literacy sebagai dasar yang baik untuk seseorang yang hendak memilih berhutang atau tidak, dikarenakan memiliki keputusan yang tepat dan matang, serta mengerti tentang resiko berhutang. Hasil ini juga sejalan dengan temuan penelitian oleh Lyons (2004) yang mengatakan bahwa apabila individu tidak memiliki financial literacy yang baik, maka seseorang akan rentan untuk mengambil produk-produk hutang yang ditawarkan di pasar yang ujungnya akan membuat kesulitan keuangan ketika menghadapi resiko gagal bayar. Pengaruh variabel financial literacy terhadap propensity to indebtedness adalah negatif atau berlawanan arah. Hal ini menunjukkan bahwa semakin tinggi financial literacy maka akan semakin rendah propensity to indebtedness. Adanya pengaruh signifikan negatif financial literacy terhadap propensity to indebtedness bahwa semakin baik literasi keuangan yang dimiliki masyarakat yang berdomisili dan bertempat tinggal di Surabaya akan membuat tidak adanya kecenderungan untuk berhutang.

Literasi keuangan yang baik dapat dilihat dari adanya ketepatan waktu dalam membayar tagihan merupakan hal yang penting bagi responden sehingga memiliki dampak yang baik, yaitu tidak memiliki hutang. Dengan demikian dapat dijelaskan bahwa masyarakat yang berdomisili dan bertempat tinggal di Surabaya dengan financial literacy yang baik, tidak akan memiliki kecenderungan untuk berhutang, karena dengan adanya pemahaman mengenai keuangan akan mengarahkan individu untuk tidak melakukan hutang dengan anggapan bahwa hutang merupakan beban bagi individu tersebut. Dengan kata lain, financial literacy sangat memiliki peran penting dalam pembentukan perilaku untuk memilih berhutang atau tidak, sehingga apabila individu tidak ingin memiliki perilaku yang cenderung berhutang maka sangat penting untuk meningkatkan financial literacy yang dimiliki.

\section{Pengaruh Compulsive Buying terhadap Propensity to Indebtedness}

Hasil analisis pengaruh compulsive buying terhadap propensity to indebtedness mempunyai nilai $\mathrm{t}$ statistik sebesar 6,204 yang artinya lebih besar dari 1,96, sehingga menunjukkan bahwa terdapat pengaruh signifikan compulsive buying terhadap propensity to indebtedness pada masyarakat yang berdomisili dan bertempat tinggal di Surabaya. Berdasarkan hasil maka hipotesis $\mathrm{H}_{2}$ yaitu 
"Compulsive buying berpengaruh signifikan terhadap perilaku propensity to indebtedness", dinyatakan diterima. Hal ini sejalan dengan pendapat Carvalho \& Alves (2010) yang menjelaskan bahwa compulsive buying yang tidak dilakukan akan membuat keuangan individu akan terjaga dengan baik dan tingkat hutangpun akan cenderung rendah. Hasil ini juga sejalan dengan temuan penelitian oleh O'Guinn \& Faber (1989) yang mengatakan bahwa apabila pembelian barangbarang material, seperti tas, pakaian, make up, dan kendaraan bermotor merupakan hal wajar, tentunya dengan pengontrolan didalam membeli barang-barang tersebut sehingga tidak sampai berhutang untuk membeli barang-barang tersebut.

Pengaruh variabel compulsive buying terhadap propensity to indebtedness adalah positif atau searah. Hal ini menunjukkan bahwa semakin rendah compulsive buying maka akan semakin rendah propensity to indebtedness. Adanya pengaruh signifikan positif compulsive buying terhadap propensity to indebtedness bahwa semakin rendah pembelian kompulsif yang dimiliki masyarakat yang berdomisili dan bertempat tinggal di Surabaya akan membuat tidak adanya kecenderungan untuk berhutang. Pembelian kompulsif yang rendah dapat dilihat dari sifat individu yang membelanjakan uang bulanannya hanya untuk membeli barang yang dibutuhkan. Selain itu, banyak responden yang membeli barang yang mampu dibeli saja sehingga mampu mengontrol pengeluaran bulanan dan tidak sampai terjadi hutang. Dengan demikian dapat dijelaskan bahwa masyarakat yang berdomisili dan bertempat tinggal di Surabaya dengan tingkat compulsive buying yang rendah, tidak akan memiliki kecenderungan untuk berhutang, karena dengan tidak adanya pembelian kompulsif akan membuat individu cenderung untuk berhemat dan tidak mengeluarkan uang secara berlebih, serta tidak akan berhutang. Dengan kata lain, compulsive buying yang rendah akan membuat individu untuk tidak berhutang.

\section{Pengaruh Materialism terhadap Propensity to Inddebtedness}

Hasil analisis pengaruh materialism terhadap propensity to indebtedness mempunyai nilai $\mathrm{t}$ statistik sebesar 7,518 yang artinya lebih besar dari 1,96, sehingga menunjukkan bahwa terdapat pengaruh signifikan materialism terhadap propensity to indebtedness pada masyarakat yang berdomisili dan bertempat tinggal di Surabaya. Berdasarkan hasil maka hipotesis $\mathrm{H}_{3}$ yaitu "Materialism berpengaruh signifikan terhadap perilaku propensity to indebtedness", dinyatakan diterima. Hal ini sejalan dengan pendapat Ponchio (2006) yang menjelaskan bahwa materialism yang rendah, semakin rendah juga propensity to indebtedness, dimana seseorang akan dapat menahan hasrat untuk membeli hal-hal materi yang mewah. Hasil ini juga sejalan dengan temuan penelitian oleh Gardarsdottir \& Dittmar (2012) yang mengatakan bahwa materialism merupakan faktor penentu seseorang dalam berhutang, sehingga materialism yang rendah membuat seseorang tidak akan berhutang demi barang-barang mewah yang diinginkan.

Pengaruh variabel materialism terhadap propensity to indebtedness adalah positif atau searah. Hal ini menunjukkan bahwa semakin rendah materialism maka akan semakin rendah propensity to indebtedness. Adanya pengaruh signifikan positif materialism terhadap propensity to indebtedness bahwa semakin rendah pembelian kompulsif yang dimiliki masyarakat yang berdomisili dan bertempat tinggal di Surabaya akan membuat tidak adanya kecenderungan untuk berhutang.

Perilaku materialisme yang rendah dapat dilihat dari sifat individu yang berpikir bahwa apabila memamerkan kekayaan didepan publik bukan merupakan tindakan yang baik. Selain itu, banyak responden yang tidak tertarik dengan hal-hal yang mewah, sehingga tidak terjadi adanya hutang 
demi memuaskan dirinya sendiri. Dengan demikian dapat dijelaskan bahwa masyarakat yang berdomisili dan bertempat tinggal di Surabaya dengan tingkat materialism yang rendah, tidak akan memiliki kecenderungan untuk berhutang, karena dengan tidak membeli sesuatu yang mewah akan membuat individu cenderung untuk menikmati apa yang dimiliki dan tidak mengeluarkan uang secara berlebih bahkan berhutang demi hal-hal mewah. Dengan kata lain, materialism yang rendah akan membuat individu untuk tidak melakukan hutang.

\section{Pengaruh Financial Literacy terhadap Compulsive Buying}

Hasil analisis pengaruh financial literacy terhadap compulsive buying mempunyai nilai t statistik sebesar 3,181 yang artinya lebih besar dari 1,96, sehingga menunjukkan bahwa terdapat pengaruh signifikan financial literacy terhadap compulsive buying pada masyarakat yang berdomisili dan bertempat tinggal di Surabaya. Berdasarkan hasil maka hipotesis $\mathrm{H}_{4}$ yaitu "Financial literacy berpengaruh signifikan terhadap perilaku compulsive buying", dinyatakan diterima. Hal ini sesuai dengan pendapat Russell et al. (2006) yang menjelaskan bahwa financial literacy dapat digunakan sebagai dasar untuk mencegah perilaku pembelian kompulsif dengan cara memberikan pendidikan keuangan sejak dini supaya pada saat memiliki penghasilan akan dapat mengatur keuangan, serta mengetahui mana yang merupakan keinginanan dan mana yang merupakan kebutuhan. Hasil ini juga sejalan dengan temuan penelitian oleh Chen \& Volpe (1998) yang mengatakan bahwa apabila individu tidak memiliki financial literacy yang baik, maka akan melek secara finansial dan membuat individu mampu untuk menahan keinginan dalam berbelanja secara berlebih.

Pengaruh variabel financial literacy terhadap compulsive buying adalah negatif atau berlawanan arah. Hal ini menunjukkan bahwa semakin tinggi financial literacy maka akan semakin rendah compulsive buying. Adanya pengaruh signifikan negatif financial literacy terhadap compulsive buying bahwa semakin baik literasi keuangan yang dimiliki masyarakat yang berdomisili dan bertempat tinggal di Surabaya akan membuat tidak adanya pembelian secara kompulsif. Literasi keuangan yang baik dapat dilihat dari banyaknya responden yang cermat terhadap potongan harga saat berbelanja sehingga mampu mengontrol pengeluaran bulanan. Dengan demikian dapat dijelaskan bahwa masyarakat yang berdomisili dan bertempat tinggal di Surabaya dengan financial literacy yang baik, tidak akan memiliki perilaku compulsive buying, karena dengan adanya pemahaman mengenai keuangan dalam berbelanja yang akan mengarahkan individu untuk tidak melakukan pembelian secara kompulsif. Dengan kata lain, financial literacy sangat memiliki peran penting dalam pembentukan perilaku dalam berbelanja, sehingga apabila individu tidak ingin memiliki perilaku dengan berbelanja secara berlebih maka sangat penting untuk meningkatkan financial literacy.

\section{Pengaruh Financial Literacy terhadap Materialism}

Hasil analisis pengaruh financial literacy terhadap materialism mempunyai nilai t statistik sebesar 2,187 yang artinya lebih besar dari 1,96, sehingga menunjukkan bahwa terdapat pengaruh signifikan financial literacy terhadap materialism pada masyarakat yang berdomisili dan bertempat tinggal di Surabaya. Berdasarkan hasil maka hipotesis $\mathrm{H}_{5}$ yaitu "Financial literacy berpengaruh signifikan terhadap perilaku materialism", dinyatakan diterima. Hal ini sesuai dengan pendapat Roberts (1998) yang menjelaskan bahwa financial literacy dapat digunakan sebagai dasar dalam praktek keuangan sebagai tindakan untuk mencegah perilaku materialistik. Hasil ini juga sejalan dengan temuan penelitian oleh Pham et al, (1998) yang mengatakan bahwa financial literacy dapat mengurangi nilai materialistis seseorang dengan cara memberikan pelatihan dasar tentang 
praktek keuangan, seperti memanajemen keuangan, penganggaran, serta menabung.

Pengaruh variabel financial literacy terhadap materialism adalah negatif atau berlawanan arah. Hal ini menunjukkan bahwa semakin tinggi financial literacy maka akan semakin rendah materialism. Adanya pengaruh signifikan negatif financial literacy terhadap materialism bahwa semakin baik literasi keuangan yang dimiliki masyarakat yang berdomisili dan bertempat tinggal di Surabaya akan membuat tidak adanya keinginan untuk membeli hal-hal mewah.

Literasi keuangan yang baik dapat dilihat dari responden yang menahan keinginannya dalam membeli barang-barang mewah. Dengan demikian dapat dijelaskan bahwa masyarakat yang berdomisili dan bertempat tinggal di Surabaya dengan financial literacy yang baik, tidak akan memiliki perilaku materialism, karena dengan adanya pemahaman mengenai keuangan, individu akan dapat mengontrol pembelian atas barang-barang mewah, dalam arti barang-barang mewah bukan hal wajib yang harus dibeli. Dengan kata lain, financial literacy sangat memiliki peran penting dalam pembentukan perilaku dalam pembelian atas barang-barang mewah, sehingga apabila individu ingin mengontrol daya beli terhadap barang-barang mewah maka financial literacy juga harus ditingkatkan.

\section{Pengaruh Materialism terhadap Compulsive Buying}

Hasil analisis pengaruh materialism terhadap propensity to indebtedness mempunyai nilai $\mathrm{t}$ statistik sebesar 11,617 yang artinya lebih besar dari 1,96, sehingga menunjukkan bahwa terdapat pengaruh signifikan materialism terhadap propensity to indebtedness pada masyarakat yang berdomisili dan bertempat tinggal di Surabaya. Berdasarkan hasil maka hipotesis $\mathrm{H}_{6}$ yaitu "Materialism berpengaruh signifikan terhadap perilaku compulsive buying", dinyatakan diterima. Hal ini sejalan dengan pendapat Dittmar (2004) yang menjelaskan bahwa individu dengan perilaku materialism yang rendah akan memiliki harga diri yang lebih tinggi dan lebih dapat menahan untuk tidak melakukan pembelian kompulsif. Hasil ini juga sejalan dengan temuan penelitian oleh Richins (2004) yang mengatakan bahwa materialism dan compulsive buying memiliki hubungan yang positif.

Pengaruh variabel materialism terhadap compulsive buying adalah positif atau searah. Hal ini menunjukkan bahwa semakin rendah materialism maka akan semakin rendah compulsive buying. Adanya pengaruh signifikan positif materialism terhadap compulsive buying bahwa semakin rendah perilaku materialistik yang dimiliki masyarakat yang berdomisili dan bertempat tinggal di Surabaya akan membuat tidak adanya pembelian kompulsif. Perilaku materialisme yang rendah dapat dilihat dari sifat individu yang berpikir bahwa membeli barang mewah demi kesenangan sesaat bukan merupakan hal yang baik. Dengan demikian dapat dijelaskan bahwa masyarakat yang berdomisili dan bertempat tinggal di Surabaya dengan tingkat materialism yang rendah, maka pembelian secara kompulisf juga rendah, karena dengan tidak membeli barang mewah berarti tidak membeli secara berlebihan atau kompulsif. Dengan kata lain, materialism yang rendah akan membuat individu untuk tidak melakukan pembelian secara kompulsif.

\section{KESIMPULAN}

Berdasarkan pada hasil pengujian hipotesis dan pembahasan, kesimpulan dalam penelitian ini antara lain: terdapat pengaruh signifikan financial literacy terhadap propensity to indebtedness pada masyarakat yang berdomisili dan bertempat tinggal di Surabaya sehingga hipotesis pertama 
dapat dinyatakan diterima dan terbukti kebenarannya; Terdapat pengaruh signifikan compulsive buying terhadap propensity to indebtedness pada masyarakat yang berdomisili dan bertempat tinggal di Surabaya sehingga hipotesis kedua dapat dinyatakan diterima dan terbukti kebenarannya; Terdapat pengaruh signifikan materialism terhadap propensity to indebtedness pada masyarakat yang berdomisili dan bertempat tinggal di Surabaya sehingga hipotesis ketiga dapat dinyatakan diterima dan terbukti kebenarannya; Terdapat pengaruh signifikan financial literacy terhadap compulsive buying pada masyarakat yang berdomisili dan bertempat tinggal di Surabaya sehingga hipotesis keempat dapat dinyatakan diterima dan terbukti kebenarannya; Terdapat pengaruh signifikan financial literacy terhadap materialism pada masyarakat yang berdomisili dan bertempat tinggal di Surabaya sehingga hipotesis kelima dapat dinyatakan diterima dan terbukti kebenarannya; Terdapat pengaruh signifikan materialism terhadap compulsive buying pada masyarakat yang berdomisili dan bertempat tinggal di Surabaya sehingga hipotesis keenam dapat dinyatakan diterima dan terbukti kebenarannya. Dari hasil tersebut, maka penelitian selanjutnya diharapkan dapat menambahkan variabel lain seperti sosio demografi supaya kemampuan dalam menjelaskan variabel independen terhadap dependen semakin bervariasi dan semakin besar.

\section{DAFTAR PUSTAKA}

(NFCS), N. F. (2013). Financial Capability in the United States-Report of Findings from the 2012 National Financial Capability Study. Financial Industry Regulatory Authority (FINRA) Investor Education Foundation, available at: www.usfinancialcapability.org/downloads/NFCS_2012_Report_Natl_Findings. pdf (accessed 7 April 2016).

Achtziger, A., Hubert, M., Kenning, P., \& Raab, G. a. (2015). Debt out of control: the links between selfcontrol, compulsive buying, and real debts. Journal of Economic Psychology, 141-149.

Atkinson, A., \& Messy, F. (2012). Measuring Financial Literacy: results of the OECD/INFE Pilot study. Paris: Working Paper No. 15, OECD Working Papers on Finance, Insurance, and Private Pensions, OECD Publishing.

Bitner, M., Gwinner, K., Dwayney, \& Gremler, D. (1990). Relational benefit in service industries: the customer's perspective. Journal of the Academy of Marketing Science, 324-346.

Carvalho, A., \& Alves, J. (2010). As relações entre o consumo das famílias brasileiras, ciclo de vida e gênero. XVII Encontro Nacional De Estudos Populacionais, ABEP.

Chen, H., \& Volpe, R. (1998). An analysis of personal financial literacy among college students. Financial Services Review, 107-128.

Davies, E., \& Lea, S. E. (1995). Student Attitudes to Student Debt. Journal of Economic Psychology.

detikfinance. (2014, Desember 5). Surabaya Jadi Kota Metropolitan Terbaik se Indonesia, Ini Kunci Sukses Risma. Retrieved from finance.detik.com: https://finance.detik.com/berita-ekonomi-bisnis/d2769367/surabaya-jadi-kota-metropolitan-terbaik-se-indonesia-ini-kunci-sukses-risma

Development, O. f.-O. (2015). OECD/INFE Toolkit for Measuring Financial Literacy and Financial Inclusion. OECD Publishing.

Dittmar, H. (2004). Understanding and diagnosing compulsive buying. Handbook of Addictive Disorders.

Erdem, C. (2008). Factors affecting the probability of credit card default and the intention of card use in Turkey. Journal of Applied Social Psychology, 1685 - 1711.

Fitch, C. (2007). Debt and mental Health. Journal of continuing professional developmnet, The Role Of Psychiatrist Apt, 194 - 202.

Gardarsdottir, R., \& Dittmar, H. (2012). The relationship of materialism to debt and financial wellbeing : the case of Iceland's perceived prosperity. Journal of Economic Psychology, 471-481.

Gathergood, J. (2011). Self-control, financial literacy and consumer over-indebtness. Social Science Research Network.

Huston, S. (2010). Measuring Financial Literacy. Journal of Consumer Affairs, 296-316. 
Klapper, L., Lusardi, A., \& Panos, G. (2013). "Financial literacy and its consequences: evidence from Russia during the financial crisis". Journal of Banking \& Finance, Vol. 37, pp. 3904-3923.

Lea, S., Webley, P., \& Walker, C. (1995). "Psychological factors in consumer debt: money management, economic socialization, and credit use". Journal of Economic Psychology, Vol. 16 No. 4, pp. 681-701.

Leite, P., Rangé, B., Ribas, R. J., Filomensky, T., \& Oliveira e Silva, A. (2011). "Tradução e adaptação semântica da compulsive buying scale Para o português brasileiro". Jornal Brasileiro De Psiquiatria, Vol. 60 No. 3, pp. 176-181.

Lusardi, A., \& Mitchell, O. (2008). Planning and financial literacy ; How do women fare? NBER Working Paper No. 13750.

Lusardi, A., \& Tufano, P. (2009). Debt literacy, financial experiences, and overindebtness. NBER Working Paper No. 14808.

Lyons, A. (2004). A profile of financially at-risk college students. The Journal of Consumer Affairs, 56-80.

Mowen, J., \& Minor, M. (2002). Consumer behavior. Upper Saddle River : Prentice Hall. Inc.

O'Guinn, T., \& Faber, R. (1989). Compulsive buying: a phenomenological exploration. Journal of Consumer Research, 147-157.

O'Neill, B., \& Xiao, J. (2012). "Financial behaviors before and after the financial crisis: evidence from an online survey". Journal of Financial Counseling and Planning, Vol. 23 No. 1, pp. 33-46.

OECD. (2012). OECD/INFE High-Level Principles on National Strategies for Financial Education. Paris: OECD Publishing.

OECD. (2013). Financial Literacy and Inclusion: Results of OECD/INFE Survey across Countries and by Gender. OECD Publishing.

Parrotta, J., \& Johnson, P. (1998). The Impact of FInancial Attitudes and Financial Knowledge on Financial Management and Satisfaction of Recently Married Individuals. Association for Financial Counseling and Planning Education.

Pham, T., Yap, K., \& Dowling, N. (2012). The impact of financial management practices and financial attitudes on the relationship between materialism and compulsive buying. Journal of Economic Psychology, 461-470.

Ponchio, M. (2006). The influence of materialism on consumption indebtedness in the context of low income consumers from the city of Sao Paulo. Escola de Administração de Empresas de São Paulo da Fundação Getúlio Vargas, 175.

Potrich, A., Vieira, K., \& and Kirch, G. (2016). Você é alfabetizado financeiramente? Descubra no termômetro de alfabetização financeira. BASE-Revista De Administração e Contabilidade Da Unisinos, 153-170.

Richins, M. (2004). The material values scale : measurement properties and development of a short form. Journal of Consumer Research, 209-219.

Roberts, J. (1998). Compulsive buying among college students: an investigation of its antecedents, consequences, and implications for public policy. Journal of Consumer Affairs, 295-308.

Shockey, S. (2002). "Low-wealth adults financial literacy. Money management behavior and associates factors, including critical thinking". Doctorate, University of Utah.

Surya. (2017, November 21). Tahun 2019, Bank Indonesia Targetkan Banked People 75 Persen. Retrieved from SURYA.co.id: http://surabaya.tribunnews.com/2017/11/21/tahun-2019-bank-indonesia-targetkanbanked-poeple-75-persen

Surya. (2018, Januari 3). Realisasi Pendapatan Pajak di Kanwil DJP Jatim I Capai 88,39 Persen. Retrieved from SURYA.co.id: http://surabaya.tribunnews.com/2018/01/03/realisasi-pendapatan-pajak-di-kanwildjp-jatim-i-capai-8839-persen

Tatzel, M. (2002). Money worlds and well-being: an integration of money dispositions, materialism and pricerelated behavior. Journal of Economic Psychology, 103-126.

Van Rooij, M., Lusardi, A., \& Alessie, R. (2011). "Financial literacy and retirement planning in The Netherlands". Journal of Economic Psychology, Vol. 32 No. 4, pp. 593-608. 